\title{
Apakah intervensi prasangka lewat media bisa mengurangi prasangka implisit terhadap orang dengan HIV/AIDS? Eksperimen menggunakan Implicit Association Test (IAT)
}

\author{
Tsana Afrani Suyono*, Prista El A. Prasetyo, Erika Shafira, Firza Yusani Tanjung, \\ Farras Syazwani, \& Whisnu Yudiana \\ Fakultas Psikologi, Universitas Padjadjaran
}

\begin{abstract}
Abstrak
Stigma negatif terhadap orang yang hidup dengan HIV/AIDS (ODHA) memunculkan suatu prasangka yang berujung pada penolakan untuk berinteraksi ataupun melakukan diskriminasi. Beberapa penelitian membuktikan bahwa prasangka terhadap ODHA dapat menurun dengan memberikan intervensi melalui beberapa jenis media komunikasi seperti gambar dan video. Hanya saja, penelitian sebelumnya lebih menekankan pada prasangka yang bersifat eksplisit (sadar) yang sangat dipengaruhi ol eh tuntutan sosial. Di sisi lain, pada dasarnya prasangka tidak hanya bersifat eksplisit, tetapi juga bersifat implisit (spontan). Dua eksperimen dilakukan dengan tujuan untuk melihat pengaruh jenis media komunikasi-berupa gambar dan video-pada perubahan prasangka implisit mahasiswa terhadap ODHA. Subjek merupakan mahasiswa aktif yang dipilih dengan menggunakan teknik sampel acak berstrata berdasarkan ti ngkatan tahun. Pendekatan penelitian adalah pre-post experimental design dengan menggunakan pengukuran prasangka implisit yaitu Implicit Association Test (IAT). Analisis data dilakukan dengan melakukan uji beda terhadap skor IAT yang diperoleh. Hasil analisa menunjukan bahwa tidak ada perbedaan skor IAT antara sebelum dan setelah perlakukan. Berdasarkan data dapat disimpulkan jenis media komunikasi berupa gambar dan video tidak mengubah prasangka implisit terhadap ODHA.
\end{abstract}

Kata kunci: prasangka, implisit, media, HIV/AIDS.

\begin{abstract}
The negative stigma towards people living with HIV/AIDS (ODHA) raises a prejudice that results in a refusal to interact or discrimination. Several studies have shown that prejudice against ODHA can be reduced by providing interventions through several types of communication media such as pictures and videos. Previous research emphasizes explicit (conscious) prejudices that are strongly influenced by social demands. On the other hand, basically prejudice is not only explicit but also implicit (spontaneous). Two experiments were conducted with the aim to see the effect of the type of communication media in the form of pictures and videos on changes in students' implicit prejudices against ODHA. Subjects were active students who were selected using stratified random sample techniques based on year levels. The research approach is a pre-post experimental design using implicit prejudice measurement namely the Implicit Association Test (IAT). Data analysis was performed by conducting different tests of the IAT scores obtained. Analysis results show that there is no difference in the IAT score between before and after treatment. Based on the data it can be concluded that the type of communication media in the form of pictures and videos does not change the implicit prejudice against ODHA.
\end{abstract}

Keywords: prejudice, implicit, media, HIV/AIDS.

\section{Pendahuluan}

Fenomena HIV/AIDS merupakan suatu fenomena sosial di Indonesia dengan jumlah kasus yang cenderung meningkat setiap tahunnya (Ardani \& Handayani, 2017). Kondisi tersebut tidak hanya mengakibatkan banyak orang yang terinfeksi HIV dan/atau mengidap AIDS (dikenal sebagai Orang Dengan HIV/AIDS; selanjutnya disingkat ODHA) dikucilkan dan dijauhi dalam pergaulan di masyarakat (Ardani \& Handayani, 2017), tetapi terkadang mereka juga kurang mendapatkan perawatan yang baik karena banyak petugas kesehatan yang masih takut untuk berurusan dengan ODHA (Wodajo, ThupayagaleTshweneagae, \& Akpor, 2017). Hal ini menunjukkan bahwa adanya prasangka masyarakat terhadap ODHA memberikan banyak dampak negatif.

Setiap tahunnya, pemerintah dan organisasi di seluruh dunia membuat banyak konten publikasi 
mengenai anti-prasangka, baik melalui pengumuman publik, publikasi internet dan cetak, program tel evisi, serta program radio (Paluck, 2009). Beberapa penelitian menunjukkan bahwa media publikasi berupa teks, gambar, dan video berdampak positifmengurangi prasangka terhadap ODHA (Creel, dkk., 2011; O'Leary, dkk., 2007; Nurhidayah, 2019). Hal ini karena prasangka dapat berubah karena adanya perubahan atau penambahan informasi yang dimiliki seseorang terhadap konteks ODHA (Lupia, dkk., 2015). Hanya saja, penelitian-penelitian tersebut menggunakan pengukuran yang bersifat eksplisit (secara sadar) melalui kuesioner. Sering kali orang yang mengklaim memiliki sikap egaliter terhadap kelompok sosial tertentu menunjukkan kecenderungan berprasangka ketika diukur secara eksplisit (Banaji \& Greenwald, 1995; Devine, dkk., 2002; Fourie, Kilchenmann, MalcolmSmith, \& Thomas, 2012; Phelps, dkk., 2000). Hal ini dapat terjadi karena adanya kecenderungan pada diri individu untuk melakukan social desirability bias (bias keinginan sosial) ketika melakukan self-report (pelaporan individu), yaitu kecenderungan untuk menjawab sesuai dengan keinginan atau tuntutan sosial (Levin, dkk., 2015; Mashuri \& Zaduqisti, 2014). Untuk menghindari hal tersebut, pengukuran terhadap prasangka dapat dilakukan cara lain yaitu secara implisit (otomatis).

Prasangka sendiri didefinisikan sebagai sikap penilaian negatif terhadap suatu kelompok dan individu yang menjadi anggotanya (Myers, 2013). Ketika seseorang memiliki prasangka terhadap individu lain, maka orang tersebut cenderung memberikan respons emosional yang negatif (Baron, 2012), melakukan penilaian tanpa mengenal lebih banyak karakteristik orang tersebut (Henry \& Sears, 2009), bahkan dapat bersikap negatif tanpa disadari terhadap orang atau kelompok yang tidak disukainya (Hafiyah, Puri, \& Shadewi, 2012). Lebih jauh menurut Myers (2013), prasangka digambarkan sebagai dual attitude system (sistem sikap ganda) pada individu yaitu prasangka yang bersifat eksplisit dan implisit dapat berbeda pada diri individu terhadap target yang sama (Banaji \& Greenwald, 2013). Dengan demikian, seseorang dapat memiliki prasangka terhadap ODHA yang berbeda antara pengukuran eksplisit ataupun implisit. Prasangka secara implisit dapat diukur melalui Implicit Association Test (IAT). IAT dapat mengukur kekuatan dari asosiasi otomatis yang dilakukan (Greenwald, Nosek, \& Banaji, 2003). Greenwald, dkk. (1998) menjelaskan bahwa IAT merupakan suatu tugas waktu reaksi yang dirancang untuk mengukur pengaruh implisit pada perilaku dengan menilai kekuatan asosiasi otomatis antara representasi mental objek (Fourie, Kilchenmann, Malcolm-Smith, \& Thomas, 2012). Lebih lanjut, pengukuran implisit dapat dilakukan untuk mengetahui penyebab psikologis dari persepsi sosial, penilaian, dan aksi yang mungkin tidak dapat diperoleh melalui pengalaman introspektif atau jawaban langsung meskipun individu dapat men-jawab secara akurat (Nosek, Hawkins, \& Frazier, 2011).
Berdasarkan asumsi tersebut, penelitian ini mencoba untuk melihat pengaruh dari jenis media komunikasi pada perubahan prasangka yang menggunakan metode pengukuran implisit. Penelitian ini menarik untuk dilakukan karena hasil dari suatu intervensi terhadap prasangka yang bersifat implisit masih belum stabil. Asumsi dasar dari prasangka yang bersifat implisit adalah cenderung lebih stabil dan berubah secara perlahan (Rydell \& McConnell, 2006). Di lain pihak, beberapa penelitian menemukan bahwa prasangka yang bersifat implisit terhadap suatu konteks dapat menurun bahkan dengan hanya menggunakan satu sesi intervensi (Columb \& Plant, 2011; Guinote, Will is, \& Martellota, 2010). Hal tersebut sebenernya terjadi karena individu yang melakukan konstruksi ulang konteks yang menjadi prasangkanya menjadi kategori yang baru dengan kata lain lebih tepat "merubah konteks yang menjadi prasangka" dibandingkan mengubah prasangka terhadap konteksnya (Monteith, Parker, \& Burns, 2016).

Dengan demikian, terdapat dua pertanyaan penelitian yang dirumuskan pada penelitian ini, yaitu "Apakah terdapat pengaruh pemberian jenis media komunikasi berupa gambar pada prasangka mahasiswa terhadap ODHA?" dan "Apakah terdapat pengaruh pemberian jenis mediakomunikasi berupa video pada prasangka mahasiswa terhadap ODHA?".

\section{Eksperimen I}

\section{Metode Penelitian}

Partisipan. Populasi penelitian ini adalah mahasiswa aktif tahun pertama, kedua, dan ketiga. Sampel tidak memiliki karakteristik khusus. Teknik pengambilan sampel dalam penelitian ini adalah teknik sampling probabilitas yaitu sampel acak berstrata. Subjek dipisahkan berdasarkan strata tingkatan tahun, dengan menggunakan sampel acak sederhana. Didapatkan 41 subjek yang menjadi sampel penelitian. Subjek laki-laki sebanyak 6 orang $(12,20 \%)$ dan subjek perempuan sebanyak 35 orang $(87,80 \%)$. Subjek mahasiswa tahun pertama berjumlah 14 orang $(34,15 \%)$, tahun kedua berjumlah 14 orang $(34,15 \%)$ dan tahun ketiga berjumlah 13 orang $(31,51 \%)$.

Desain. Desain penelitian yang digunakan pada eksperimen ini adalah one-group pretest-posttest only design, yaitu desain penelitian yang mana kondisi perlakuan diselingi antara pra-tes dan pasca-tes dari variabel terikat (Christensen, 2007). Untuk mengukur prasangka, subjek akan mengerjakan IAT sebagai bentuk pra-tes. Kemudian, dilanjutkan dengan pemberian perlakuan berupa pemaparan gambar kepada subjek yang bertujuan untuk mengurangi prasangka terhadap ODHA. Setiap gambaryang disajikan dalam waktu 30 detik. Waktu tersebut didasarkan pada kemampuan mengingat individu yang mana informasi akan masuk ke dalam working memory individu setelah sensori menerima informasi minimal selama 30 detik (Matlin, 2013). Selanjutnya, subjek akan kembali diminta mengerjakan IAT sebagai bentuk pasca-tes. 
Hasil pra-tes dan pasca-tes selanjutnya dibandingkan untuk melihat apakah terdapat perbedaan diantara keduanya yang menunjukkan efektivitas perlakuan yang diberikan. One-group pretest-posttest only design bersifat within karena kelompok subjek yang diteliti hanya berjumlah satu kelompok. Hasil yang diharapkan dari menggunakan desain ini adalah untuk melihat perubahan sikap prasangka subjek antara sebelum dan sesudah diberikan perlakuan. Penelitian ini juga berfokus pada perbedaan internal diri individu dengan tidak mengadakan kelompok kontrol sebagai perbandingan.

Prosedur. Setelah subjek bersedia untuk mengikuti penelitian, subjek diinformasikan mengenai jadwal dan tempat pelaksanaan penelitian yaitu di ruangan monitor laboratorium Fakultas Psikologi Universitas Padjadjaran. Prasangka akan diukur meng-gunakan IAT, sebuah alat yang disusun untuk mengukur kekuatan asosiasi konsep target dan dimensi atribut (Greenwfdsald, Nosek, \& Banaji, 2003).

MenurutEgloff dan Schmukle (2002), asumsi dasar IAT adalah jika terdapat dua konsep yang sangat terkait, tugas penyortiran yang dilakukan akan lebih mudah (sehingga lebih cepat) ketika dua konsep yang berkaitan memiliki kunci respon yang sama daripada ketika mereka berbagi kunci respon yang berbeda. IAT dapat mengukur tindakan implisit pada kontrol sadar, dan, dengan demikian, faktor respons dan batas introspektif (Greenwald, dkk., 2002; Egloff \& Schmukle, 2002) tidak mengurangi validitasnya. Egloff dan Schmukle (2002) menyatakan bahwa bentuk perilaku yang relatif spontan, seperti perilaku nonverbal atau reaktivitas fisiologis, harus dikaitkan dengan tes implisit karena semua tindakan yang dilakukan memiliki kemungkinan merupakan upaya individu untuk tampil dengan cara yang tidak negatif. Alat ukur IAT dibuat menggunakan perangkat lunak Open Sesame, yakni perangkat lunak pembuat eksperimen grafis untuk penelitian di bidang ilmu sosial (Mathôt, Schreij, \& Theeuwes, 2012). Eksperimen dalam penelitian ini memiliki total 14 blok uji coba yang masing-masing berjumlah tujuh blok pada pra-tes dan pasca-tes. Pada bagian awal setiap blok uji coba, terdapat instruksi untuk mengategorikan dua kelompok stimulus yang akan muncul pada layar dengan menggunakan tombol ' $\mathrm{E}$ dan 'I' pada papan ketik. Kelompok pasangan stimulus yang pertama adalah ODHA dan SEHAT. Kategori ODHA terdiri dari satu buah gambar ilustrasi ODHA, kata 'HIV', 'Virus', 'Jarum Suntik', dan 'Pergaulan Bebas'. Kategori SEHAT terdiri dari satu buah gambar ilustrasi orang sehat, kata 'Higienis', 'Stamina', 'Lincah', dan 'Kuat'. Kelompok pasangan stimulus yang kedua adalah Baik dan Buruk. Kategori Baik berisi kata 'Hebat', 'Menarik', 'Menyenangkan', 'Keren', dan 'Gembira'. Kategori Buruk berisi kata 'Menjijikkan', 'Menakutkan', 'Menyebalkan', 'Menyakitkan', dan 'Menyedihkan' (Yusaini, Thohari, \& Gustomy, 2016).

Blok pertama terdiri dari 20 pertanyaan dan subjek bertugas untuk mengategorikan kata ke dalam kategori ODHA dan SEHAT. Blok kedua terdiri dari 20 pertanyaan dan subjek bertugas untuk mengategorikan kata ke dalam kategori Baik dan Buruk. Blok ketiga terdiri dari 20 pertanyaan dan subjek bertugas untuk mengategorikan kata dalam kategori ODHA dengan kategori Buruk dan kata dalam kategori SEHAT dengan kategori Baik. Blok keempat terdiri dari 40 pertanyaan dan subjek bertugas untuk mengategorikan kata dalam kategori ODHA dengan kategori Buruk dan kata dalam kategori SEHAT dengan kategori Baik. Blok kelima terdiri dari 40 pertanyaan dan subjek bertugas untuk mengategorikan kata dalam kategori ODHA dengan kategori Baik dan kata dalam kategori SEHAT dengan kategori Buruk. Blok keenam terdiri dari 20 pertanyaan dan subjek bertugas untuk mengategorikan kata dalam kategori ODHA dengan kategori Baik dan kata dalam kategori SEHAT dengan kategori Buruk. Blok ketujuh terdiri dari 40 pertanyaan dan subjek bertugas untuk mengategorikan kata dalam kategori ODHA dengan kategori Baik dan kata dalam kategori SEHAT dengan kategori Buruk.

Jenis media komunikasi yang digunakan sebagai perlakuan terhadap subjek adalah gambar berisi fakta-fakta mengenai ODHA. Jumlah gambar yang dipergunakan sebanyak 15 gambar yang diperoleh dari situs-situs Google. Pada gambar, dicantumkan fakta-fakta mengenai ODHA yang informasinya diperoleh dari situs kesehatan yaitu Alodokter dan HelloSehat.

Teknik analisis. Skala pengukuran yang digunakan dalam penelitian ini adalah skala interval, dengan menghitung perbedaan skor IAT sebelum dan sesudah diberikan perlakuan berupa gambar-gambar yang memuat informasi mengenai ODHA. Untuk mendapatkan skor IAT, data diolah menggunakan R studio. Skor IAT adalah selisih antara skor prasangka yang diperoleh berdasarkan reaction time. Jika skor IAT yang diperoleh positif, maka artinya individu memiliki prasangka yang positif terhadap ODHA. Jika skor IAT yang diperoleh negatif, maka artinya individu memiliki prasangka yang negatif terhadap ODHA.

Hasil dari perlakuan yang diberikan dapat dilihat dari perubahan positif dan/atau negatif dari skor IAT yang telah diperoleh. Jika sebelum mendapatkan perlakuan individu memiliki IAT skor negatif, kemudian setelah mendapatkan perlakuan individu memiliki IAT skor yang positif, maka dapat dikatakan bahwa perlakuan yang diberikan efektif dalam mengubah prasangka individu. Analisis hasil IAT dilakukan dengan menggunakan Z-score (Wen, Fan, Ye, \& Chen, 2016).

Kemudian, hasil dari data pra-tes dan pascates akan diuji normalitasnya dengan menggunakan uji Kolmogorov-Smirnov (Gravetter, 2013). Jika data berdistribusi normal statistik inferensial akan diuji dengan uji t dan jika data tidak berdistribusi normal akan diuji dengan uji Wilcoxon dengan menggunakan perangkat lunak SPSS (Siegel \& Castellan, 1988). Untuk uji normalitas, data dapat dikatakan berdistribusi normal apabila $p$-value $>\alpha$ dan $\alpha=0,05$ (Gravetter, 2013). Untuk uji statistik inferensial, data 
dapat dikatakan memiliki hasil yang signifikan apabila $p$-value $<\alpha$ dan $\alpha=0,05$ (Siegel \& Castellan, 1988). Kriteria uji yang dituju oleh peneliti yaitu untuk IAT Score (d) prates individu adalah d positif yang dan IAT Score (d) pasca-tes individu adalah $d$ negatif.

\section{Hasil Penelitian}

Berdasarkan tabel 1, diketahui bahwa skor IAT prates pada seluruh subjek memiliki statistik deskriptif $(\mathrm{M}=0,0868$ dan $\mathrm{SD}=0,8769)$ dan skor IAT pasca-tes pada seluruh subjek memiliki statistik deskriptif $(\mathrm{M}=$ $-0,0093, \mathrm{SD}=0,7605)$. Diketahui pada subjek laki-laki, skor IAT pra-tes memiliki statistik deskriptif $(\mathrm{M}=$ $0,0199, \mathrm{SD}=0.8394$ ) dan skor IAT pasca-tes memiliki statistik deskriptif $(\mathrm{M}=-0,1524, \mathrm{SD}=0,6325)$. Skor IAT pra-tes pada subjek perempuan memiliki statistik deskriptif $(\mathrm{M}=0,1051, \mathrm{SD}=0,893)$ dan skor IAT pasca-tes memiliki statistik deskriptif $(\mathrm{M}=0,0153$ dan $\mathrm{SD}=0,7857$ ).

Normalitas data diolah menggunakan perangkat lunak SPSS dengan uji Kolmogorov-Smirnov. Pada IAT skor hasil prates diperoleh hasil bahwa normalitas data $\mathrm{P}=0,002$ dan $\mathrm{p}<0,05$ sehingga kesimpulannya data tidak berdistribusi normal. Untuk IAT skor hasil pascates diperoleh hasil bahwa normalitas data $\mathrm{P}=0,023$ dan $\mathrm{p}<0,05$ sehingga kesimpulannya, data tidak berdistribusi normal. Dengan data yang tidak berdistribusi normal, uji statistik dilakukan dengan menggunakan uji Wilcoxon dengan hasil Ho diterima $(\mathrm{Z}=-0,901, p$-value $=0,368)$. Dengan $p>0,05$. dapat disimpulkan tidak terdapat perbedaan yang signifikan antara skor IAT sebelum diberi paparan gambar dan setelah diberi paparan gambar yang memuat informasi mengenai ODHA.

Penghitungan terhadap skor IAT menggunakan perangkat lunak R studio dengan kriteria uji effect size (d) pra-tes individu adalah d positif dan effectsize (d) pasca-tes individu adalah d negatif. Pada tabel 2, dapat dilihat bahwa sebanyak tiga subjek berada pada kategori pertama, yaitu kategori effect size (d) pra-tes individu adalah d positif dan effect size (d) pasca-tes individu adalah d negatif. Artinya, penelitian ini cukup efektif untuk mengubah prasangka tiga individu, dari yang awalnya memiliki prasangka terhadap ODHA menjadi tidak memiliki prasangka. Tidak terdapat subjek yang berada pada kategori kedua, yaitu kategori effect size (d) pra-tes individu adalah d negatif dan effectsize (d) pasca-tes individu adalah d positif. Artinya, pemberian perlakuan tidak mengubah sikap individu menjadi memiliki prasangka terhadap ODHA. Pada kategori ketiga, terdapat 17 subjek yang memiliki effect size (d) pra-tes individu adalah d positif dan effectsize (d) pasca-tes individu adalah d positif, artinya penelitian ini tidak cukup efektif untuk mengubah prasangka 17 individu yang memiliki prasangka terhadap ODHA. Kemudian, sebanyak 21 subjek berada pada kategori keempat, yaitu d negatif dan effect size (d) pasca-tes individu adalah d negatif. Artinya, sebelum diberikan perlakuan, subjek diketahui tidakmemiliki prasangka terhadap ODHA sehingga pemberian perlakuan tidak memengaruhi subjek.

Tabel 1

Statistik Deskriptif dan InferensialSubjek

\begin{tabular}{lccc}
\hline & $\begin{array}{c}\text { Pra-tes } \\
\text { M (SD) }\end{array}$ & $\begin{array}{c}\text { Pasca-tes } \\
\text { M (SD) }\end{array}$ & $\begin{array}{c}\text { Wilcoxon } \\
(\mathrm{Z}, \mathrm{p} \text {-value })\end{array}$ \\
\hline Keseluruhan & $0,0868(0,8769)$ & $-0,0093(0,7605)$ & $(-0,901 ; 0,368)$ \\
Laki-Laki & $-0,0199(0,8394)$ & $-0,1524(0,7857)$ & \\
Perempuan & $0,1051(0,8937)$ & $0,0153(0,7857)$ & \\
\hline
\end{tabular}

Tabel 2

EffectSize Subjek

\begin{tabular}{lll}
\hline Pra-tes & Pasca-tes & Jumlah Subjek \\
\hline Positif & Negatif & 3 \\
Negatif & Positif & 0 \\
Positif & Positif & 17 \\
Negatif & Negatif & 21 \\
\hline
\end{tabular}




\section{Diskusi}

Media komunikasi merupakan salah satu jenis media massa yang memiliki peran dalam membentuk kepercayaan dan perilaku berprasangka, memunculkan, dan mengurangi prasangka dan konflik (Paluck, 2009). Namun, hasil dari penelitian ini menunjukkan bahwa media komunikasi berupa gambar tidak memiliki pengaruh terhadap prasangka mahasiswa pada ODHA. Hal ini ditandai dengan tidak adanya perbedaan effect size pada pra-tes dan pasca-tes individu. Tidak berpengaruhnya media gambar pada prasangka mahasiswa terhadap ODHA mungkin disebabkan karena gambar yang diberikan tidak memiliki medium penyampaian informasi yang cukup nyata (Myers, 2013), sehingga tidak mengubah atau menambah informasi yang dimiliki oleh individu (Lupia, dkk, 2015). Hal ini dijelaskan oleh Myers (2013) yang mengungkapkan bahwa semaki nyata medium informasinya, maka semakin persuasif sifat informasinya. Hasil penelitian Brown dan Paterson (2016) juga menunjukkan bahwa terdapat kemungkinan apabila paparan informasi yang diberikan lebih nyata, maka sikap dan intensi perilaku individu dapat berubah ke arah yang lebih positif. Sebagaimana dirangkum dalam riset sebelumnya (lihat Paluck, 2009), efek media pada orang dewasa tidaklah diketahui. Orang dewasa mungkin dapat merespons secara berbeda dan memiliki sikap yang lebih sulit untuk diubah, mengingat subjek dalam penelitian ini berusia 18 sampai 21 tahun, yang termasuk dalam kategori orang dewasa (Santrock, 2018).

Tidak terjadinya perubahan prasangka pada individu juga dapat disebabkan oleh kepercayaan dalam diri individu yang sangat sulit untuk diubah meskipun media dapat memengaruhi kepercayaan atau keyakinan itu (Paluck, 2009). Kepercayaan atau keyakinan yang didefinisikan sebagai pemahaman mengenai lingkungan dan diri sendiri merupakan komponen penting dalam tingkat prasangka seseorang. Sebelumnya juga dikemukakan bahwa keyakinan individu mungkin berubah, tetapi stereotip masyarakat tidak akan berubah dalam waktu lama. Perspektif ini memprediksi bahwa efek dari program suatu media mungkin lemah sehingga tidak terjadi perubahan prasangka dalam waktu singkat Pada penelitian ini, subjek hanya diberi paparan sebanyak satu kali saja, sehingga sulit untuk meyakini bahwa keyakinan atau prasangka mereka akan mengalami perubahan, meskipun Columb dan Plant (2011) serta Guinote dan kolega (2010) mengemukakan bahwa prasangka yang bersifat implisit dapat menurun hanya dengan menggunakan satu sesi intervensi. Waktu paparan yang singkat mungkin tidak menambah atau mengubah informasi yang dimiliki individu terhadap konteks ODHA, sehingga prasangka tidak berubah secara signifikan.

Dalam penelitian, subjek diberikan paparan 15 gambar yang menunjukkan fakta-fakta mengenai ODHA dalam satu pertemuan. Paluck (2009) menyatakan bahwa aktivitas yang simultan dapat ber- dampak pada persuasi dari ketertarikan dalam komunikasi. Namun, perlu diketahui bahwa paparan yang berulang kali, waktu yang terlalu lama, dan terus menerus dapat menyebabkan kebosanan dan rasa terganggu. Selain itu disebutkan pula bahwa faktorfaktor tersebut dapat menguatkan, melemahkan, atau tidak memiliki efek terhadap hubungan antara paparan media dan prasangka, serta hal tersebut tidak dapat diketahui secara pasti. Paparan gambar yang diberikan dalam penelitian ini memiliki kemungkinan untuk membuat subjek merasa bosan, sehingga menyebabkan tidak terjadinya perubahan pada prasangka subjek terhadap ODHA secara signifikan.

\section{Eksperimen II}

\section{Metode Penelitian}

Partisipan. Didapatkan 41 subjek yang menjadi sampel penelitian. Namun, terdapat 4 subjek yang tidak dapat mengikuti sesi pemberian perlakuan dari penelitian, sehingga tersisa 38 subjek yang mengikuti penelitian hingga selesai. Setiap subjek mengikuti eksperimen sebanyak tiga kali pertemuan. Subjek dengan jenis kelamin laki-laki sebanyak 6 orang $(15,79 \%)$ dan jumlah subjek perempuan sebanyak 32 orang $(84,21 \%)$. Subjek yang berasal dari tahun pertama berjumlah 13 orang $(34,21 \%)$, tahun kedua berjumlah 12 orang $(31,58 \%)$, dan tahun ketiga berjumlah 13 orang $(34,21 \%)$. Subjek berusia 17 tahun berjumlah 2 orang $(2,65 \%)$, berusia 18 tahun berjumlah 10 orang $(26,31 \%)$, berusia 19 tahun berjumlah 15 orang $(39,47 \%)$, dan berusia 20 tahun berjumlah 12 orang $(31,57 \%)$.

Desain. Pendekatan yang digunakan dalam penelitian ini adalah pendekatan eksperimen menggunakan quasi experimental design. Quasi experimental design adalah desain eksperimental yang tidak mengontrol pengaruh seluruh variabel luar (Christensen, 2007). Dalam hal ini, eksperimen dilakukan sebanyak tiga pertemuan di hari yang berbeda. Artinya, subjek tidak dikontrol sepenuhnya oleh peneliti selama proses penelitian berlangsung. Pengalaman ataupun pengetahuan yang diperoleh subjek dalam kurun waktu tiga hari di luar dari waktu penelitian tersebut merupakan suatu hal yang tidak dapat dikontrol oleh peneliti. Adapun pada penelitian ini juga digunakan one-group pretest-posttest only design.

Prosedur. Penelitian ini terbagi dalam tiga pertemuan. Pada pertemuan pertama, subjek diminta untuk mengerjakan IAT sebagai bentuk pra-tes. Setelah mengerjakan IAT, subjek diberikan paparan video sebagai sesi perlakuan pertama. Pada pertemuan kedua, dilakukan sesi perlakuan selama 20 menit dengan menonton video. Pada pertemuan ketiga, subjek terlebih dahulu diminta untuk menonton video ketujuh sebagai sesi perlakuan terakhir. Setelah perlakuan diberikan, subjek diminta untuk 
mengerjakan Implicit Association Test (IAT) sebagai bentuk pasca-tes.

Setiap selesai menonton video, subjek diarahkan untuk menjawab pertanyaan-pertanyaan seputar isi dari konten video. Hal ini dilakukan dengan tujuan untuk memastikan bahwa subjek memahami isi pesan dari video yang ditampilkan. Pada penelitian ini, pemberian perlakuan menggunakan video didukung oleh penelitian sebelumnya yang menunjukkan bahwa pemberian psikoedukasi dapat dilakukan melalui pemaparan video kepada subjek (Komatsu, dkk., 2012). Selain itu, penelitian yang dilakukan oleh Jahraus, dkk. (2002) menyatakan bahwa psikoedukasi dengan pemberian video dapat dilakukan selama 20 menit.

\section{Hasil Penelitian}

Berdasarkan Tabel 3, diketahui bahwa skor IAT prates pada seluruh subjek memiliki statistik deskriptif $(\mathrm{M}=0,1766, \mathrm{SD}=0,5519)$ dan skor IAT pasca-tes pada seluruh subjek memiliki statistik deskriptif (M = $0,2138, S D=0,53338)$. Pada subjek laki-laki diketahui skor IAT prates memiliki statistik deskriptif $(\mathrm{M}=$ $0,3586, \mathrm{SD}=0,48122$ ) dan skor IAT pasca-tes memiliki statistik deskriptif $(M=0,2973, S D=0,49002)$. Skor IAT pra-tes pada subjek perempuan memiliki statistik deskriptif $(\mathrm{M}=0,1424, \mathrm{SD}=0,56441)$ dan skor IAT pasca-tes pada subjek perempuan memiliki statistik $\operatorname{deskriptif}(M=01981, S D=0,54702)$.

Normalitas data diolah dengan menggunakan perangkat lunak SPSS dengan uji Kolmogorov-Smirnov. Pada IAT skor prates diperoleh hasil bahwa normalitas data $\mathrm{P}=0,003$ dan $p$-value $<$ 0,05 sehingga kesimpulannya data tidak berdistribusi normal. Pada IAT skor pasca-tes diperoleh hasil bahwa normalitas data $\mathrm{P}=0,146$ dan $p$-value $>0,05$ sehingga kesimpulannya, data berdistribusi tidak normal. Dengan data yang tidak berdistribusi normal, uji statistik akan dilakukan dengan menggunakan uji Wilcoxon dengan hasil Ho diterima $(\mathrm{Z}=-0.718, p$ value $=0.473$ ). Dengan $\mathrm{p}>0,05$ dapat disimpulkan, tidak terdapat perbedaan yang signifikan antara skor IAT sebelum diberi paparan video dan setelah diberi paparan video yang memuat informasi mengenai ODHA.

Penghitungan terhadap skor IAT menggunakan perangkat lunak $\mathrm{R}$ studio dengan kriteria uji effect size (d) pra-tes individu adalah d positif dan effectsize (d) pasca-tes individu adalah d negatif. Pada tabel 4, sebanyak dua subjek berada pada kategori pertama, yaitu kategori effectsize (d) pra-tes individu adalah d positif dan effect size (d) pasca-tes individu adalah d negatif. Artinya, penelitian ini cukup efektif untuk mengubah prasangka dua individu, dari yang awalnya memiliki prasangka terhadap ODHA menjadi tidak memiliki prasangka. Terdapat empat subjek yang berada pada kategori kedua, yaitu kategori effect size (d) pra-tes individu adalah d negatif dan effect size (d) pasca-tes individu adalah d positif. Artinya, pemberian perlakuan mengubah sikap empat individu menjadi memiliki prasangka terhadap ODHA.

Pada kategori ketiga, terdapat 20 subjek yang memiliki effectsize (d) pra-tes individu adalah d positif dan effect size (d) pasca-tes individu adalah d positif, artinya penelitian ini tidak cukup efektif untuk mengubah prasangka 20 individu yang memiliki prasangka terhadap ODHA. Kemudian, sebanyak 12 subjek berada pada kategori keempat, yaitu d negatif dan effectsize (d) pasca-tes individu adal ah d negatif. Artinya, sebelum diberikan perlakuan, subjek diketahui tidak memiliki prasangka terhadap ODHA sehingga pemberian perlakuan tidak memengaruhi subjek.

\section{Diskusi}

Penelitian ini dilakukan dengan tujuan untuk mengetahui apakah terdapat pengaruh jenis media komunikasi berupa video terhadap prasangka pada ODHA menggunakan IAT. Namun, pada penelitian ini, media komunikasi berupa video tidak memiliki pengaruh pada perubahan prasangka mahasiswa terhadap ODHA. Hal ini berbeda dengan hasil penelitian Creel dan kolega (2011), O'Leary dan kolega (2007), dan Nurhidayah (2019) yang menunjuk-kan bahwa video berdampak positif terhadap penurunan prasangka terhadap ODHA. Tidak berpengaruhnya video terhadap perubahan prasang-ka mahasiswa terhadap ODHA pada penelitian ini dapat disebabkan karena efek media pada orang dewasa tidaklah diketahui, yang mana orang dewasa mungkin merespons secara berbeda dan memiliki sikap yang lebih sulit untuk diubah (Paluck, 2009). Sebagaimana yang dikemukakan oleh Lupia dan kolega (2015), bahwa perlu adanya perubahan atau penambahan informasi yang dimiliki seseorang terhadap konteks ODHA agar prasangka dapat berubah. Hasil penelitian ini menunjukkan bahwa jenis media komunikasi berupa video tidak memiliki pengaruh pada prasangka mahasiswa yang sebagian besar berada di rentang usia dewasa.

Konsisten dengan Eksperimen 1, kepercayaan atau keyakinan yang dipengaruhi program atau media serta budaya bisa berubah, akan tetapi konten stereotipe mungkin lebih sulit berubah. Dengan kata lain, perubahan tidak bisa terjadi dengan cepat. Pada penelitian ini, subjek hanya diberi paparan video sebanyak tiga pertemuan dalam rentang waktu yang singkat, sehingga sulit untuk meyakini bahwa keyakinan atau prasangka mereka akan berubah. Namun, sebagaimana disebutkan dalam Eksprimen 1, literatur sebelumya mencatat bahwa satu sesi intervensi dianggap cukup. Dalam hal ini, diperlukan usaha dari individu untuk melakukan konstruksi ulang konteks yang menjadi prasangkanya (Monteith, Parker \& Burns, 2016). 
Tabel 3

Statistik Deskriptifdan Inferensial Subjek

\begin{tabular}{lccc}
\hline & \multicolumn{1}{c}{$\begin{array}{c}\text { Pra-tes } \\
\text { M (SD) }\end{array}$} & $\begin{array}{c}\text { Pasca-tes } \\
\text { M (SD) }\end{array}$ & $\begin{array}{c}\text { Wilcoxon } \\
\text { (Z, p-value) }\end{array}$ \\
\hline Keseluruhan & $0,1766(0,5519)$ & $0,2138(0,5334)$ & $(-0,718 ; 0,473)$ \\
Laki-Laki & $0,3586(0,4812)$ & $0,2973(0,49)$ & \\
Perempuan & $0,1424(0,5644)$ & $0,1981(0,5470)$ & \\
\hline
\end{tabular}

Tabel 4

EffectSize Subjek

\begin{tabular}{lll}
\hline Pra-tes & Pasca-tes & \multicolumn{2}{l}{ Jumlah Subjek } \\
\hline Positif & Negatif & 2 \\
Negatif & Positif & 4 \\
Positif & Positif & 20 \\
Negatif & Negatif & 12 \\
\hline
\end{tabular}

\section{Gambar 1}

EffectSize Subjekpada Media Komunikasi Gambar dan Video

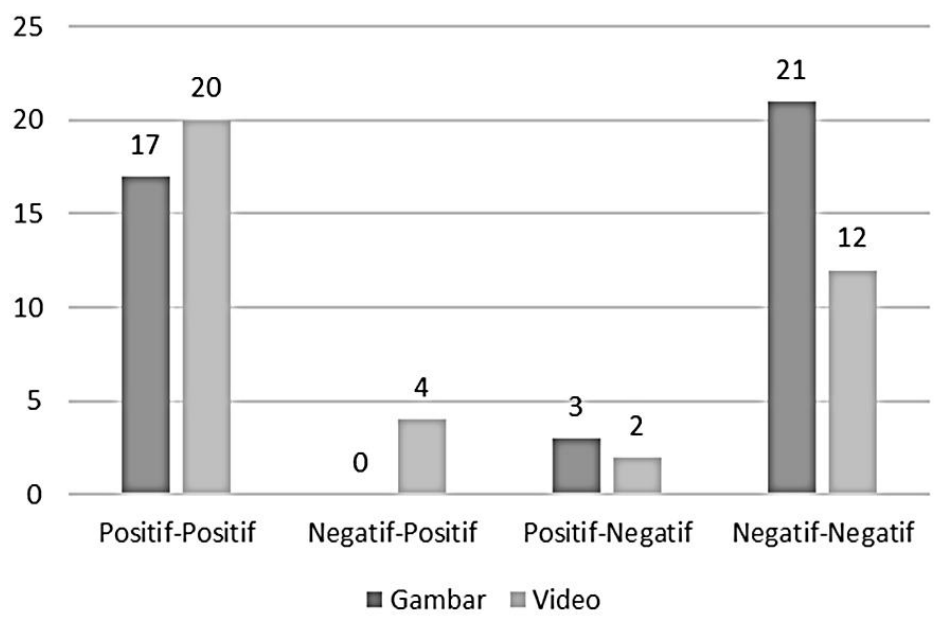

Media komunikasi membentuk prasangka dengan melibatkan persuasi yang memiliki dua jalur, yaitu central route dan peripheral route. Penelitian ini memberikan paparan video berisi informasi yang menyasar pada central route. Menurut Myers (2013), central route merupakan cara pengelolaan informasi dalam kognitif dengan menelaah informasi yang diberikan oleh media secara analitis. Pada penelitian ini, subjek diberikan paparan video mengenai faktafakta ODHA dan pengalaman hidup dari ODHA dalam tiga sesi pertemuan. Aktivitas yang simultan dapat berdampak pada persuasi dari ketertarikan dalam komunikasi (Paluck, 2009). Sebagaimana pada di eksperimen 1, paparan video yang diberikan dalam penelitian ini memiliki kemungkinan untuk membuat subjek merasa bosan, sehingga menyebabkan tidak terjadinya perubahan pada prasangka subjek terhadap ODHA secara signifikan.

\section{Diskusi Umum}

Pada penelitian ini, pemisahan analisis demografi berdasarkan jenis kelamin laki-laki dan perempuan dilakukan karena berdasarkan penelitian yang dilakukan oleh Ekehammar, Akrami, dan Araya (2003). Dari penelitian tersebut, diketahui bahwa terdapat perbedaan prasangka implisit pada laki-laki maupun perempuan, yang mana perempuan memiliki 
prasangka implisit yang lebih tinggi dibandingkan dengan laki-laki. Namun, hal tersebut tidak terbukti pada penelitian ini. Penelitian ini menunjukkan bahwa media komunikasi berupa gambar dan video tidak berpengaruh secara signifikan pada prasangka mahasiswa terhadap orang dengan HIV /AIDS (ODHA) yang mungkin disebabkan oleh waktu pemberian treatmentyang terlalu singkat, meskipun Columb dan Plant (2011) serta Guinote dan kolega (2010) mengemukakan bahwa prasangka yang bersifat implisit dapat menurun hanya dengan menggunakan satu sesi intervensi. Meskipun begitu, pengukuran sikap implisit dengan menggunakan IAT dapat memprediksi tingkah laku individu yang berkaitan dengan prasangka, yang mungkin tidak dapat terukur dengan menggunakan pengukuran eksplisit (Nosek, Hawkins, \& Frazier, 2011). Hal inilah yang menjadi kekuatan IAT untuk digunakan dalam berbagai konteks penelitian. Pengukuran implisit yang dilakukan dengan menggunakan IAT tidak ditujukan untuk mengubah sikap individu, tetapi untuk melengkapi pengukuranpengukuran sebelumnya mengenai sikap. Berdasarkan hal tersebut, studi ini menegaskan bahwa untuk mengubah prasangka yang dimiliki individu, perlu ditinjau lebih lanjut mengenai media intervensi yang digunakan. Yang mana, pada penelitian ini, media yang digunakan berupa gambar dan video.

Berdasarkan penelitian yang dilakukan oleh Earnshaw, dkk. (2015), diketahui bahwa peningkatan kontak sosial terhadap kelompok dengan stigma tertentu dan memeroleh pengetahuan mengenai hal tersebut dapat mengurangi prasangka pada diri individu. Selain itu, menghilangkan kebiasaan berprasangka terhadap suatu kelompok tertentu dengan meningkatkan kesadaran, kepedulian, dan upaya juga dapat mengurangi prasangka yang dimiliki individu (Forscher, dkk., 2017). Implikasinya, cara untuk mengurangi sikap implisit bisa dengan meregulasi ataupun mengontrol prasangka (Stangor, 2016); bukan dengan menyangkal atau menghindarinya.

Asumsi dasar dari prasangka yang bersifat implisit adalah cenderung lebih stabil dan berubah secara perlahan (Rydell \& McConnell, 2006). Untukitu, mengubah prasangka individu harus dilakukan secara bertahap. Intervensi yang dapat digunakan untuk mengurangi prasangka selain menggunakan media komunikasi adalah dengan melalui cooperative learning, berdiskusi, berhubungan secara langsung dengan pihak yang mendapatkan prasangka, pelatihan cross-cultural, kategorisasi sosial, konsistensi nilai dan self-worth, pelatihan kognitif (Paluck \& Green, 2009), serta membayangkan melakukan kontak dengan pihak yang mendapatkan prasangka (West, Holmes, \& Hewstone, 2011). Dengan membay-angkan interaksi dengan pihak lain di luar kelompok, individu dapat memiliki persepsi yang lebih positif mengenai outgroups tersebut (Crisp \& Turner, 2009; Paluck \& Green, 2009) dan mengurangi prasangka terhadap kelompoktersebut (West, Holmes, \& Hewstone, 2011).

\section{Kesimpulan}

Sampai saat ini, masyarakat Indonesia masih menyematkan stigma negatif terhadap Orang dengan HIV/AIDS (ODHA). Stigma negatif tersebut memunculkan suatu prasangka yang berujung pada penolakan untuk berinteraksi maupun diskriminasi terhadap ODHA. Hal tersebut tentu menyebabkan dampak negatif bagi ODHA. Media massa berperan dalam pembentukan prasangka pada individu. Penelitian ini dilakukan dengan tujuan untuk melihat pengaruh jenis media komunikasi pada perubahan prasangka terhadap ODHA. Hasil dari penelitian ini, ditemukan bahwa tidak terdapat perbedaan yang signifikan antara skor IAT sebelum diberi paparan gambar atau video dan setelah diberi paparan gambar atau video yang memuat informasi mengenai ODHA. Artinya, pemberian jenis media komunikasi secara signifikan tidak memengaruhi perubahan prasangka pada partisipan.

\section{Keterbatasan dan saran}

Keterbatasan atau limitasi pada penelitian ini yaitu adanya keterbatasan waktu dalam memberikan perlakuan terhadap individu. Diketahui bahwa sikap merupakan suatu hal yang tidak mudah untuk diubah dalam jangka waktu yang singkat, sehingga pemberian perlakuan dengan frekuensi yang sedikit tidak dapat memberikan efek yang signifikan. Selain itu, terdapat beberapa variabel luaryang tidak dapat dikontrol oleh peneliti. Namun, tidak menutup kemungkinan bahwa penelitian ini dapat dilakukan kembali dengan menambah frekuensi serta durasi dari pemaparan media.

Saran lain yang dapat diberikan terhadap penelitian selanjutnya adalah dengan memperhatikan faktor-faktor yang dapat memengaruhi sikap pada individu, seperti rasa kebosanan dan terganggu yang mungkin dapat dirasakan oleh individu. Selain itu, pengembangan terhadap prosedur dan instrumen dari perlakuan yang diberikan juga dapat dilakukan. Misalnya, dengan menciptakan video psikoedukasi mengenai fakta-fakta orang dengan HIV/AIDS yang masih jarang diketahui oleh masyarakat Indonesia.

\section{Daftar Pustaka}

Abe, N. (2009). The neurobiology of deception: evidence from neuroimaging and loss-offunction studies. Current Opinion in Neurology, 22(6), 594-600.

Adolphs, R. (2001). The neurobiology of social cognition. Current Opinion in Neurobiology, 11(2), 231-239. https://doi.org/10.1016/S09594388(00)00202-6

Akitsuki, Y., \& Decety, J. (2009). Social context and perceived agency affects empathy for pain: an event-related fMRI investigation. Neuroimage, 47(2), 722-734. 
Alkire, M. T., Hudetz, A. G., \& Tononi, G. (2008). Consciousness and anesthesia. Science, 322(5903), 876-880.

Alloway, T. P., \& Alloway, R. G. (2010). Investigating the predictive roles of working memory and IQ in academic attainment. Journal of Experimental Child Psychology, 106(1), 20-29.

Armalita, R., \& Helmi, A. F. (2018). Iri di Situs Jejaring Sosial: Studi tentang Teori Deservingness. Jurnal Psikologi, 45(3), 218-230.

Baess, P., Zhdanov, A., Mandel, A., Parkkonen, L, Hirvenkari, L., Mäkelä, J. P., ... Hari, R. (2012). MEG dual scanning: a procedure to study realtime auditory interaction between two persons. Frontiers in Human Neuroscience, 6, 83.

Bailey, D. L., Maisey, M. N., Townsend, D.W., \& Valk, P. E. (2005). Positron emission tomography. Springer.

Bastiaansen, M. C. M., Van Berkum, J. J. A., \& Hagoort, P. (2002). Syntactic processing modulates the $\theta$ rhythm of the human EEG. Neuroimage, 17(3), 1479-1492.

Benson, J., Greaves, W., O’Donnell, M., \& Taglialatela, J. (2002). Evidence for symbolic language processing in a bonobo (Pan paniscus). Journal of Consciousness Studies, 9(12), 33-56.

Boly, M., Phillips, C., Tshibanda, L., Vanhaudenhuyse, A., Schabus, M., Dang-Vu, T. T., ... Laureys, S. (2008). Intrinsic brain activity in altered states of consciousness: how conscious is the default mode of brain function? Annals of the New York Academy of Sciences, 1129, 119.

Boos, M., Pritz, J., Lange, S., \& Belz, M. (2014). Leadership in moving human groups. PLoS Computational Biology, 10(4), e1003541.

Boucsein, W. (2012). Electrodermal activity. Springer Science \& Business Media.

Brunoni, A. R., Nitsche, M. A., Bolognini, N., Bikson, M. Wagner, T., Merabet, L., ... Pascual-Leone, A. (2012). Clinical research with transcranial direct current stimulation (tDCS): challenges and future directions. Brain Stimulation, 5(3), 175-195.

Burg, D., Szumski, A. J., Struppler, A., \& Velho, F. (1973). Afferent and efferent activation of human muscle receptors involved in reflex and voluntary contraction. Experimental Neurology, 41(3), 754-768.

Byrne, D., \& Nelson, D. (1965). Attraction as a linear function of proportion of positive reinforcements. Journal of Personality and Social Psychology, 1(6), 659.

Cacioppo, J. (2007). Psychology is a hub science. Aps Observer, 20(8).

Cacioppo, J. T., Berntson, G. G., Adolphs, R., Carter, C. S., McClintock, M. K., Meaney, M. J., ... Taylor, S. E. (2002). Foundations in social neuroscience. MIT press.

Cantlon, J. F., \& Brannon, E. M. (2006). Shared system for ordering small and large numbers in monkeys and humans. Psychological Science, 17(5), 401-406.

Choi, K.-M., Jung, H.-J., Lee, H.-J., \& Cho, S.-W. (2007). Feasibility study of an MR damper-based smart passive control system employing an electromagnetic induction device. Smart Materials and Structures, 16(6), 2323.

Compton, R. J. (2003). The interface between emotion and attention: A review of evidence from psychology and neuroscience. Behavioral and Cognitive Neuroscience Reviews, 2(2), 115129.

Costa Jr, P. T., \& McCrae, R. R. (2008). The Revised NEO Personality Inventory (NEO-PI-R).

Crawley, J. N. (2007). What's wrong with my mouse?: behavioral phenotyping of transgenic and knockout mice. John Wiley \& Sons.

Dawson, M. E., Rissling, A. J., Schell, A. M., \& Wilcox, R. (2007). Under what conditions can human affective conditioning occur without contingency awareness? Test of the evaluative conditioning paradigm. Emotion, 7(4), 755.

Day, R. E. (2001). The modern invention of information: Discourse, history, and power. SIU Press.

de la Fuente, J., Fernández-Cabezas, M., Cambil, M., Vera, M. M., González-Torres, M. C., \& ArtuchGarde, R. (2017). Linear relationship between resilience, learning approaches, and coping strategies to predict achievement in undergraduate students. Frontiers in Psychology, 8, 1039.

Decety, J., Jackson, P. L., Sommerville, J. A., Chaminade, T., \& Meltzoff, A. N. (2004). The neural bases of cooperation and competition: an fMRI investigation. Neuroimage, 23(2), 744-751.

Di Chiro, G., DeLaPaz, R. L., Brooks, R. A., Sokoloff, L, Kornblith, P. L., Smith, B. H., ... Johnston, G. S. (1982). Glucose utilization of cerebral gliomas measured by [18F] fluorodeoxyglucose and positron emission tomography. Neurology, 32(12), 1323.

Dimoka, A. (2012). How to Conduct a Functional Magnetic Resonance (fMRI) Study in Social Science Research. MIS Quarterly, 36(3), 811840. https://doi.org/10.2307/41703482

Dumas, G., Nadel, J., Soussignan, R., Martinerie, J., \& Garnero, L. (2010). Inter-brain synchronization during social interaction. PloS One, 5(8), e12166.

Edelman, G. M., Gally, J. A., \& Baars, B. J. (2011). Biology of consciousness. Frontiers in Psychology, 2, 4.

Edwards, P. K. (2013). Neuroscience and reductionism: Some realist reflections. Birmingham Business School Discussion Paper Series.

Ekman, P. E., \& Davidson, R. J. (1994). The nature of emotion: Fundamental questions. Oxford University Press.

Embick, D., Hackl, M., Schaeffer, J., Kelepir, M., \& Marantz, A. (2001). A 
magnetoencephalographic component whose latency reflects lexical frequency. Cognitive Brain Research, 10(3), 345-348.

Fässler, R., Martin, K., Forsberg, E., Litzenbarger, T., \& Iglesias, A. (1995). Knockout mice: How to make them and why. The immunological approach. International Archives of Allergy and Immunology, Vol. 106, pp. 323-334. https://doi.org/10.1159/000236862

Faturochman, F., Kurnianingsih, S., Kurniastuti, I., \& Fathoni, N. S. (2011). The Role of Inter Ethnic Marriage on Trustworthy and Caution. Jurnal Psikologi UGM, 38(1).

Ferguson, J. N., Young, L. J., \& Insel, T. R. (2002). The neuroendocrine basis of social recognition Frontiers in Neuroendocrinology, 23(2), 200224.

Fiske, S. T., Cuddy,A. J. C., \& Glick, P. (2007). Universal dimensions of social cognition: warmth and competence. Trends in Cognitive Sciences, 11(2), 77-83. https://doi.org/10.1016/j.tics.2006.11.005

Forthmann, B., Holling, H., Çelik, P., Storme, M., \& Lubart, T. (2017). Typing speed as a confounding variable and the measurement of quality in divergent thinking. Creativity Research Journal, 29(3), 257-269.

Freeman, W. J., \& Rogers, L. J. (2002). Fine temporal resolution of analytic phase reveals episodic synchronization by state transitions in gamma EEGs. Journal of Neurophysiology, 87(2), 937945.

Fregni, F., Nitsche, M. A., Loo, C. K., Brunoni, A. R, Marangolo, P., Leite, J., ... Paik, N.-J. (2015). Regulatory considerations for the clinical and research use of transcranial direct current stimulation (tDCS): review and recommendations from an expert panel. Clinical Research and Regulatory Affairs, 32(1), 22-35.

Fresan, A., Camarena, B., Apiquian, R., Aguilar, A., Urraca, N., \& Nicolini, H. (2007). Association study of MAO-A and DRD4 genes in schizophrenic patients with aggressive behavior. Neuropsychobiology, 55(3-4), 171175.

Frick, A., Åhs, F., Engman, J., Jonasson, M., Alaie, I., Björkstrand, J., ... Appel, L. (2015). Serotonin synthesis and reuptake in social anxiety disorder: a positron emission tomography study. JAMA Psychiatry, 72(8), 794-802.

Fukushi, T., Sakura, O., \& Koizumi, H. (2007). Ethical considerations of neuroscience research: The perspectives on neuroethics in Japan. Neuroscience Research, 57(1),10-16.

Gazzaniga, M., \& Heatherton, T. (2015). Psychological Science: Fifth International Student Edition. WW Norton \& Company.

Gazzaniga, M. S. (2014). Handbook of cognitive neuroscience. Springer.

Ghatak, S., Muthukumaran, R. B., \& Nachimuthu, S. K. (2013). A simple method of genomic DNA extraction from human samples for PCR-RFLP analysis. Journal of Biomolecul ar Techniques: JBT, 24(4), 224-231. https://doi.org/10.7171/jbt.13-2404-001

Goense, J., Bohraus, Y., \& Logothetis, N. K. (2016). fMRI at high spatial resolution: implications for BOLD-models. Frontiers in Computational Neuroscience, 10, 66.

Gold, J. I., \& Shadlen, M. N. (2007). The neural basis of decision making. Annual Review of Neuroscience, 30.

Goldberg, E., Harner, R., Lovell, M., Podell, K., \& Riggio, S. (1994). Cognitive bias, functional cortical geometry, and the frontal lobes: laterality, sex, and handedness. Journal of Cognitive Neuroscience, 6(3), 276-296.

Goldschmidt, A. B., Wonderlich, S. A., Crosby, R. D., Engel, S. G., Lavender, J. M., Peters on, C. B., ... Mitchell, J. E. (2014). Ecological momentary assessment of stressful events and negative affect in bulimia nervosa. Journal of Consulting and Clinical Psychology, 82(1), 30.

Greenberg, G. (2005). The limitations of behaviorgenetic analyses: Comment on McGue, Elkins, Walden, and Iacono (2005). Developmental Psychology, 41(6), 989-992. https://doi.org/10.1037/0012-1649.41.6.989

Greene, J. D., \& Paxton, J. M. (2009). Patterns of neural activity associated with honest and dishonest moral decisions. Proceedings of the National Academy of Sciences, 106(30), 12506-12511.

Guse, B., Falkai, P., \& Wobrock, T. (2010). Cognitive effects of high-frequency repetitive transcranial magnetic stimulation: a systematic review. Journal of Neural Transmission, 117(1), 105-122.

Hampshire, A., Highfield, R. R., Parkin, B. L., \& Owen, A. M. (2012). Fractionating human intelligence. Neuron, 76(6), 1225-1237.

Han, S., \& Northoff, G. (2008). Culture-sensitive neural substrates of human cognition: A transcultural neuroimaging approach. Nature Reviews Neuroscience, 9(8), 646.

Hansen, P., Kringelbach, M., \& Salmelin, R. (2010). MEG: an introduction to methods. Oxford university press.

Heatherton, T. F. (2004). Introduction to special issue on social cognitive neuroscience. Journal of Cognitive Neuroscience, 16(10), 1681-1682.

Hedden, T., Ketay, S., Aron, A., Markus, H. R., \& Gabrieli, J. D. E. (2008). Cultural influences on neural substrates of attentional control. Psychological Science, Vol. 19, pp. 12-17. https://doi.org/10.1111/j.14679280.2008.02038.x

Henry, J. C. (2006). Electroencephalography: basic principles, clinical applications, and related fields. Neurology, 67(11), 2092.

Herculano-Houzel, S. (2009). The human brain in numbers: a linearly scaled-up primate brain. Frontiers in Human Neuroscience, 3, 31. 
Higgins, E. T. (2000). Social cognition: learning about what matters in the social world. European Journal of Social Psychology, 30(1), 3-39. https://doi.org/10.1002/(sici)10990992(200001/02)30:1<3::aidejsp987>3.0.co;2-i

Hofstede, G., Hofstede, G. J., \& Minkov, M. (2005). Cultures and organizations: Software of the mind (Vol. 2). Citeseer.

Horn, J. L., \& Cattell, R. B. (1966). Refinement and test of the theory of fluid and crystallized general intelligences. Journal of Educational Psychology, 57(5), 253.

Huang, B., Law, M. W.-M., \& Khong, P.-L. (2009). Whole-body PET/CT scanning: estimation of radiation dose and cancer risk. Radiology, 251(1), 166-174.

Huettel, S. A., Payne, J. W., Yoon, C., Gonzalez, R, Bettman, J., Hedgcock, W., \& Rao, A. (2009). Integrating neural and decision sciences: Convergence and constraints. Journal of Marketing Research, 46(1), 14-24.

Iacoboni, M. (2009). Imitation, empathy, and mirror neurons. Annual Review of Psychology, 60, 653-670.

Iacoboni, M., Lieberman, M. D., Knowlton, B. J., Molnar-Szakacs, I., Moritz, M., Throop, C. J., \& Fiske, A. P. (2004). Watching social interactions produces dorsomedial prefrontal and medial parietal BOLD fMRI signal increases compared to a resting baseline. Neuroimage, 21(3), 1167-1173.

Illes, J., \& Bird, S. J. (2006). Neuroethics: a modern context for ethics in neuroscience. Trends in Neurosciences, 29(9), 511-517.

Jacobson, L., Javitt, D. C., \& Lavidor, M. (2011). Activation of inhibition: diminishing impulsive behavior by direct current stimulation over the inferior frontal gyrus. Journal of Cognitive Neuroscience, 23(11), 3380-3387.

Jamaluddin, S. F., Adi, S. P., \& Lufityanto, G. (2020). Social influences on cheating in collectivistic culture: Collaboration but not competition Group Dynamics: Theory, Research, and Practice. Advance online publication. https://doi.org/10.1037/gdn0000122

Ju Lan, T. (2011). Heterogeneity, politics of ethnicity, and multiculturalism: What is a viable framework for Indonesia? Wacana, 13(2), 279-292.

Kacen, J. J., \& Lee, J. A. (2002). The influence of culture on consumer impulsive buying behavior. Journal of Consumer Psychology, 12(2), 163176.

Kanai, R., Paulus, W., \& Walsh, V. (2010). Transcranial alternating current stimulation (tACS) modulates cortical excitability as assessed by TMS-induced phosphene thresholds. Clinical Neurophysiology, 121(9), 1551-1554.

Kantowitz, B. H., Roediger III, H. L., \& Elmes, D. G. (2014). Experimental psychology. Nelson Education.
Karton, I., Palu, A., Jõks, K., \& Bachmann, T. (2014). Deception rate in a "lying game": different effects of excitatory repetitive transcranial magnetic stimulation of right and left dorsolateral prefrontal cortex not found with inhibitory stimulation. Neuroscience Letters, $583,21-25$.

Kéri, S., \& Kiss, I. (2011). Oxytocin response in a trust game and habituation of arousal. Physiology \& Behavior, 102(2), 221-224.

Kidd, R. F. (1976). Manipulation checks: advantage or disadvantage? Representative Research in Social Psychology.

Klimesch, W., Schimke, H., \& Schwaiger, J. (1994). Episodic and semantic memory: an analysis in the EEG theta and alpha band. Electroencephalography and Clinical Neurophysiology, 91(6), 428-441.

Kosslyn, S. M., Cacioppo, J. T., Davidson, R. J., Hugdahl, K., Lovallo, W. R., Spiegel, D., \& Rose, R. (2002). Bridging psychology and biology: The analysis of individuals in groups. American Psychologist, 57(5), 341-351. https://doi.org/10.1037/0003-066X.57.5.341

Kowalczyk, W. J., Phillips, K. A., Jobes, M. L., Kennedy, A. P., Ghitza, U. E., Agage, D. A., ... Preston, K. L. (2015). Clonidine maintenance prolongs opioid abstinence and decouples stress from craving in daily life: a randomized controlled trial with ecological momentary assessment. American Journal of Psychiatry, 172(8), 760767.

Lajante, M. M. P., Droulers, O., \& Amarantini, D. (2017). How Reliable Are "State-of-the-Art" Facial EMG Processing Methods?: Guidelines for Improving the Assessment Of Emotional Valence in Advertising Research. Journal of Advertising Research, 57(1), 28-37.

Lamm, C., Batson, C. D., \& Decety, J. (2007). The neural substrate of human empathy: effects of perspective-taking and cognitive appraisal. Journal of Cognitive Neuroscience, 19(1), 4258.

Lanzenberger, R. R., Mitterhauser, M., Spindelegger, C., Wadsak, W., Klein, N., Mien, L.-K., ... Sacher, J. (2007). Reduced serotonin-1A receptor binding in social anxiety disorder. Biological Psychiatry, 61(9), 1081-1089.

Locke, E. A. (1965). The relationship oftask success to task liking and satisfaction. Journal of Applied Psychology, 49(5), 379.

Logothetis, N. K., Pauls, J., Augath, M., Trinath, T., \& Oeltermann, A. (2001). Neurophysiological investigation of the basis of the fMRI signal. Nature, 412(6843), 150.

Lorberbaum, J. P., Kose, S., Johnson, M. R., Arana, G. W., Sullivan, L. K., Hamner, M. B., ... Bohning, D. E. (2004). Neural correlates of speech anticipatory anxiety in generalized social phobia. Neuroreport, 15(18), 2701-2705.

Lufityanto, G., Donkin, C., \& Pearson, J. (2016). Measuring intuition: nonconscious emotional 
information boosts decision accuracy and confidence. Psychological Science, 27(5), 622634.

Lufityanto, G., Purnamaningsih, E.H., Fitriani, S.D., Jehandut, B.A., Huda, T.N., Sarah, N., \& Abdillah, C.A.Z. (2019). Penggunaan peta visual terhadap kemampuan visual-spasial pengendara ojek online. Manuscript in Preparation

Lufityanto, G., Rahapsari, S., \& Kamal, I. (2020). Identifikasi stress terhadap perubahan melalui pengukuran kognitif dan respon hypothalamic-pituitary-adrenal. Jumal Psikologi Integratif, 7(2), 77-92.

Mantini, D., Corbetta, M., Romani, G. L., Orban, G. A., \& Vanduffel, W. (2012). Data-driven analysis of analogous brain networks in monkeys and humans during natural vision. Neuroimage, 63(3), 1107-1118.

Maxwell, S. E., Lau, M. Y., \& Howard, G. S. (2015). Is psychology suffering from a replication crisis? What does "failure to replicate" really mean? American Psychologist, 70(6), 487.

Milner, B., Squire, L. R., \& Kandel, E. R. (1998). Cognitive neuroscience and the study of memory. Neuron, 20(3), 445-468.

Minati, L., Visani, E., Dowell, N. G., Medford, N., \& Critchley, H. D. (2011). Variability comparison of simultaneous brain near-infrared spectroscopy and functional magnetic resonance imaging during visual stimulation. Journal of Medical Engineering \& Technology, 35(6-7), 370-376 https://doi.org/10.3109/03091902.2011.595 533

Montagu, J. D., \& Coles, E. M. (1966). Mechanism and measurement of the galvanic skin response. Psychological Bulletin, 65(5), 261.

Moorman, R. H., \& Podsakoff, P. M. (1992). A metaanalytic review and empirical test of the potential confounding effects of social desirability response sets in organizational behaviour research. Journal of Occupational and Organizational Psychology, 65(2), 131149.

Muellbacher, W., Ziemann, U., Boroojerdi, B., \& Hallett, M. (2000). Effects of low-frequency transcranial magnetic stimulation on motor excitability and basic motor behavior. Clinical Neurophysiology, 111(6), 1002-1007.

Naqvi, N. H., \& Bechara, A. (2006). Skin conductance: A psychophysiological approach to the study of decision making. Methods in Mind, 103-122.

Newport, C., Wallis, G., Reshitnyk, Y., \& Siebeck, U. E. (2016). Discrimination of human faces by archerfish (Toxotes chatareus). Scientific Reports, 6, 27523.

Newsome, S., Day, A. L., \& Catano, V. M. (2000). Assessing the predictive validity of emotional intelligence. Personality and Individual Differences, 29(6), 1005-1016.
Nitsche, M. A., Cohen, L. G., Wassermann, E. M., Priori, A., Lang, N., Antal, A., ... Fregni, F. (2008). Transcranial direct current stimulation: state of the art 2008. Brain Stimulation, 1(3), 206223.

O'Craven, K. M., \& Kanwisher, N. (2000). Mental imagery of faces and places activates corresponding stimulus-specific brain regions. Journal of Cognitive Neuroscience, 12(6), 1013-1023.

Papadelis, C., Grant, P. E., Okada, Y., \& Preissl, H. (2015). Editorial on emerging neuroimaging tools for studying normal and abnormal human brain development. Frontiers in Human Neuroscience, 9, 127.

Pascual-Marqui, R. D., Michel, C. M., \& Lehmann, D. (1994). Low resolution electromagnetic tomography: a new method for localizing electrical activity in the brain. International Journal of Psychophysiology, 18(1), 49-65.

Pavlova, M., Guerreschi, M., Lutzenberger, W., Sokolov, A. N., \& Krägeloh-Mann, I. (2010). Cortical response to social interaction is affected by gender. Neuroimage, 50(3), 13271332.

Pfaus, J. G., Damsma, G., Nomikos, G. G., Wenkstem, D. G., Blaha, C. D., Phillips, A. G., \& Fibiger, H. C. (1990). Sexual behavior enhances central dopamine transmission in the male rat. Brain Research, 530(2), 345-348.

Purpura, D. P., \& McMurtry, J. G. (1965). Intracellular activities and evoked potential changes during polarization of motor cortex. Journal of Neurophysiology, 28(1), 166-185.

Rizzolatti, G., \& Craighero, L. (2004). The mirrorneuron system. Annu. Rev. Neurosci., 27, 169192.

Rozin, P. (2001). Social psychology and science: Some lessons from solomon asch. Personality and Social Psychology Review, 5(1), 2-14. https://doi.org/10.1207/S15327957PSPR050 1_1

Sanfey, A. G., Loewenstein, G., McClure, S. M., \& Cohen, J. D. (2006). Neuroeconomics: cross-currents in research on decision-making. Trends in Cognitive Sciences, 10(3), 108-116.

Saxe, R. (2006). Uniquely human social cognition. Current Opinion in Neurobiology, 16(2), 235239. https://doi.org/10.1016/j.conb.2006.03.001

Schultz, W. (2007). Behavioral dopamine signals. Trends in Neurosciences, 30(5), 203-210.

Seloni, G. (2018). Mekanisme emotion-based learning yang dimoderatori risk-taking propensity dalam konteks pengambilan keputusan berisiko pada wirausaha dan non-wirausaha. Universitas Gadjah Mada.

Selye, H. (1950). Stress and the general adaptation syndrome. British Medical Journal, 1(4667), 1383.

Shadlen, M. N., \& Newsome, W.T. (2001). Neural basis of a perceptual decision in the parietal cortex 
(area LIP) of the rhesus monkey. Journal of Neurophysiology, 86(4), 1916-1936.

Shrout, P. E., \& Rodgers, J. L. (2018). Psychology, science, and knowledge construction: Broadening perspectives from the replication crisis. Annual Review of Psychology, 69, 487510.

Smedslund, J. (2016). Why Psychology Cannot be an Empirical Science. Integrative Psychological and Behavioral Science, 50(2), 185-195. https://doi.org/10.1007/s12124-015-9339-x

Song, A. W., Huettel, S. A., \& McCarthy, G. (2006). Functional neuroimaging: Basic principles of functional MRI. Handbook of Functional Neuroimaging of Cognition, 2, 22-52.

Spekman, R. E. (1979). Influence and information: An exploratory investigation of the boundary role person's basis of power. Academy of Management Journal, 22(1), 104-117.

Stagg, C. J., \& Nitsche, M. A. (2011). Physiological basis of transcranial direct current stimulation. The Neuroscientist, 17(1),37-53.

Stam, C. J. (2010). Use of magnetoencephalography (MEG) to study functional brain networks in neurodegenerative disorders. Journal of the Neurological Sciences, 289(1-2), 128-134.

Stefanski, V., \& Engler, H. (1999). Social stress, dominance and blood cellular immunity. Journal of Neuroimmunology, 94(1-2), 144152.

Stemmer, B., Segalowitz, S. J., Witzke, W., \& Schönle, P. W. (2004). Error detection in patients with lesions to the medial prefrontal cortex: an ERP study. Neuropsychologia, 42(1), 118-130.

Sterzer, P., Stadler, C., Poustka, F., \& Kleinschmidt, A. (2007). A structural neural deficit in adolescents with conduct disorder and its association with lack of empathy. Neuroimage, 37(1), 335-342.

Sue Carter, C. (1998). Neuroendocrine perspectives on social attachment and love. Psychoneuroendocrinology, 23(8), 779-818. https://doi.org/10.1016/S03064530(98)00055-9

Sun, S., \& Yu, R. (2014). The feedback related negativity encodes both social rejection and explicit social expectancy violation. Frontiers in Human Neuroscience, 8, 556.

Taber-Thomas, B. C., Asp, E. W., Koenigs, M., Sutterer, M., Anderson, S. W., \& Tranel, D. (2014). Arrested development: early prefrontal lesions impair the maturation of moral judgement. Brain, 137(4), 1254-1261.

Tan, P. Z., Forbes, E. E., Dahl, R. E., Ryan, N. D., Siegle, G. J., Ladouceur, C. D., \& Silk, J. S. (2012). Emotional reactivity and regulation in anxious and nonanxious youth: A cell-phone ecological momentary assessment study. Journal of Child Psychology and Psychiatry, 53(2), 197-206.

Teplan, M. (2002). Fundamentals of EEG measurement. Measurement Science Review, 2(2), 1-11.
Tong, F. (2003). Cognitive neuroscience: Primary visual cortex and visual awareness. Nature Reviews Neuroscience, 4(3), 219.

Triandis, H. C. (2001). Individual ism-collectivism and personality. Journal of Personality, 69(6), 907924.

Triantafyllou, C., Hoge, R. D., \& Wald, L. L. (2006). Effect of spatial smoothing on physiological noise in high-resolution fMRI. Neuroimage, 32(2), 551-557.

Trisia, M. A., Osozawa, K., \& Bai, H. (2016). How to Feed 311 Million of Indonesian People by 2050? Advancing Local Food Adaptation and Food Security Policy. KnE Life Sciences, 49-54.

Valkenburg, P. M., Peter, J., \& Schouten, A. P. (2006). Friend networking sites and their relationship to adolescents' well-being and social selfesteem. CyberPsychology \& Behavior, 9(5), 584-590.

Weisel, O., \& Shalvi, S. (2015). The collaborative roots of corruption. Proceedings of the National Academy of Sciences of the United States of America, 112(34), 10651-10656. https://doi.org/10.1073/pnas.1423035112

Wexler, B. E., Warrenburg, S., Schwartz, G. E., \& Janer, L. D. (1992). EEG and EMG responses to emotion-evoking stimuli processed without conscious awareness. Neuropsychologia, 30(12), 1065-1079.

Wheless, J. W., Castillo, E., Maggio, V., Kim, H. L., Breier, J. I., Simos, P. G., \& Papanicolaou, A. C. (2004). Magnetoencephalography (MEG) and magnetic source imaging (MSI). The Neurologist, 10(3), 138-153.

Wilson, S. J., Smyth, J. M., \& MacLean, R. R. (2013). Integrating ecological momentary assessment and functional brain imaging methods: new avenues for studying and treating tobacco dependence. Nicotine \& Tobacco Research, 16(Suppl_2), S102-S110.

Winston, J. S., Strange, B. A., O’Doherty, J., \& Dolan, R. J. (2002). Automatic and intentional brain responses during evaluation of trustworthiness of faces. Nature Neuroscience, 5(3), 277.

Wu, Y., Leliveld, M. C., \& Zhou, X. (2011). Social distance modulates recipient's fairness consideration in the dictator game: An ERP study. Biological Psychology, 88(2-3), 253262.

Xiang, Y., Kong, F., Wen, X., Wu, Q., \& Mo, L. (2016). Neural correlates of envy: regional homogeneity of resting-state brain activity predicts dispositional envy. Neuroimage, 142, 225-230.

Zahrani, D. D., \& Lufityanto, G. (2019). Redefining Career Success in Agile Companies: A Psychophysical Approach. Universitas Gadjah Mada. 